\title{
Understanding Factors of Distraction among Intrastate Bus Driver
}

\author{
Muhammad Nur Annuar Mohd Yunos ${ }^{1,}{ }^{*}$, Jalil Azlis-Sani ${ }^{1}$, Mohd Zamani Bin Ngali ${ }^{1}$, \\ Musli Mohammad $^{1}$, Mohd Saiful Izwan Aazizi ${ }^{2}$ and S.M. Sabri S.M. Ismail ${ }^{3}$ \\ ${ }^{1}$ Faculty of Mechanical and Manufacturing Engineering, Universiti Tun Hussein Onn Malaysia, \\ 86400 Batu Pahat, Johor, Malaysia \\ ${ }^{2}$ Rapid Bus Sdn Bhd, Kompleks Rapid Bus Cheras Selatan, 71, Jalan Kb 2/15, Kampung Baru \\ Balakong, 43300 Seri Kembangan, Selangor, Malaysia \\ ${ }^{3}$ Prasarana Malaysia Berhad, Level 21, Tower B, Menara UOA Bangsar, No 5, Jalan Bangsar Utama \\ 1, 59000 Kuala Lumpur, Malaysia
}

\begin{abstract}
The increase in number of the world population have affected the demand for public transport especially in larger cities. Intrastate buses are chosen as the main public transport by many people due to its affordable fares. Therefore, a better performance of the intrastate bus drivers would be significant to cater the high demand. Nevertheless, distraction among the intrastate bus drivers have been found as one of the major factors that could affect the performance of the drivers. Therefore, the objective of this paper is to provide a better understanding on the factors of distraction among intrastate bus drivers. This paper refers to findings from previous researches which are related to this field of study. In conclusion, this paper will provide a list of factors of distraction among the intrastate bus drivers which may degrade their performance.
\end{abstract}

\section{Introduction}

In this globalisation era, developing countries prioritised on improvement of public transport systems especially on bus services due to high demands. Department of Economic and Social Affairs (DESA) of United Nation projected that Asia population will increase approximately 1.4 million by 2050 and thus, around $86 \%$ of the world population will live in urban areas [1]. The rapid urbanisation will result in serious traffic congestion [2]. Throughout the world, public bus services are widely provided in many countries due to the popularity and affordable services for the citizens [3]. In addition, the usage of bus services could provide a significant reduction in traffic congestion [4]. With the increasing demand, public bus services are required to provide much more effective services to cater the growth of urban activities [5]. Therefore, the performance of the bus drivers may degrade due to greater workload [6].

\footnotetext{
*Corresponding author: muhdnurannuar@gmail.com
} 
The performance of the bus drivers is crucial for the public transportation industry to ensure high quality of service as well as safety of all the passengers. 50 years back, there were a lot of researches on the performance of the bus drivers [7]. Bus drivers are often exposed to various factors which would affect their performance. Buses have been identified as one of the main public transport where large proportion are involved in Road Traffic Crashes (RTC) [8]. The drivers' behaviour contributed approximately 90 percent in road crashes as well as accidents [9]. Reports from World Health Organisation (WHO) shows that about 1.24 million fatalities and approximately 20 to 50 million injuries occur due to road crashes annually [10]. Based on the annual report from Social Security Organization Malaysia (PERKESO), the accidents reported which involved buses had been gradually increasing from 2009 to 2014. Therefore, it is significant for the bus operating companies to identify the factors of distraction that affect the performance of bus drivers in order to reduce the risk and fatality involving road crashes.

In Malaysia, bus services are being chosen and prioritized by citizens due to the safety attribute provided by the bus services [11]. Annual report of 2014 from Land Public Transport Commission (SPAD) found that the most often chosen public transport by Malaysian passengers are Rapid KL. Therefore, a better performance of bus drivers could increase customers' trust as well as improving the level of comfort of passengers while riding the buses.

\section{Literature Review}

Driver distraction is one of the key factors in traffic accidents. Driver distraction can be defined as any activities which would divert the attention and focus of the driver from driving safely [12]. There are many factors that could influence the drivers. In this research, all the factors that could distract the drivers are labelled as Factors of Distraction (FoD). Factors of Distraction is defined as any factors that is distracting the intrastate bus drivers and thus, affecting their performance [13]. Meanwhile, driver distraction is a situation where the attention of the driver is diverted to any other forms of activities which may affect the concentration of the driving activity as well as safety of the passengers [13].

\subsection{Factors of Distraction (FoD)}

There are many distractions that have been identified based on previous researches. Factors of distraction could arise either from inside or outside of the vehicle [14].

\subsubsection{Technology Distraction}

It is undeniable that technology has been developed to assist and improve human life in many ways. Nevertheless, technologies may often be a form of distraction to humans. In this context of intrastate bus drivers, technologies such as mobile phones, broadcast radio as well as ticketing machines are the common technology devices being used. There are many researches that are related to technology distraction especially mobile phones. The usage of mobile phone while driving has been proven to degrade the performance of the drivers [15].

\subsubsection{Operational Distraction}

Operational distraction is referred as any operation that is necessary to be conducted by the intrastate bus drivers while carrying out their job. In Malaysia, most of the prominent bus companies are giving extra tasks to their bus drivers which is not only limited to driving the 
buses. They are also required to run the ticketing machine when the passengers ride on the buses. Besides, there is also a form of network communication between the bus drivers and the bus traffic controller. Both these operations have been proven to be the factors of distraction to the intrastate bus drivers [14].

\subsubsection{Passenger Distraction}

Passenger distraction is defined as any form of distractions that arises from the passengers. For instance, situations where passengers are talking via mobile phone with a loud voice would cause distraction to the bus drivers. Some bus drivers may be distracted by the conversation of that particular passenger rather than focusing on driving the bus. In addition, the conversation between the passengers may distract the drivers as well. In another scenario, bus drivers could also be distracted due to passengers' behaviour such as fighting among passengers, babies crying loudly or rude and mischievous children[16].

\subsubsection{Bus-Cabin Distraction}

Bus cabin distraction could be distractions that occur from the cabin equipment such as seat belt, driver seat, bus window and others [17]. This kind of distraction is commonly related to ergonomics factors.

\subsubsection{Personal-Belongings Distraction}

Personal belongings of the bus drivers may be one of the factors that will cause distraction to the bus drivers. For instance, distraction could occur when the wallet of the bus driver has dropped under the seat when driving. Therefore, the response of the bus driver to reach the wallet would affect their focus and safety of the bus. Thus, personal belongings would affect the concentration of the bus drivers as well [17].

\subsubsection{Environmental Distraction}

Environment could also become one of the main distraction for the intrastate bus drivers when performing their duty. Environmental distraction can be referred as the change of weather including heavy rain or bright sunlight. The bus drivers would have to pay more attention ensure safety of the passengers on board. Therefore, the environment should be considered as one of the distraction that may occur to the bus drivers [14].

\subsubsection{Infrastructure Distraction}

Infrastructure distraction is a type of distraction that occur to the intrastate bus drivers due to the infrastructure outside of the vehicle. Several examples of infrastructure outside of the vehicle that may distract the bus drivers include roadside advertisement [18].

\subsubsection{Road-Based Distraction}

Road-based distraction is any form of distractions that may occur because of the roadway condition. This distraction is often related to the road conditions [19]. These distractions can occur when the drivers glance off-road while driving. The period of glance of the drivers is directly proportional to the risk of causing a road crash. The risk of exposure to road accident increases with the period of the driver's glance off the road. 


\subsubsection{Health Distraction}

Health of the intrastate bus drivers could be a serious factor that require more attention as it can cause great distractions to the bus drivers. Bus driver has been identified as one of the professions with the worst health condition based on the health indicator including cholesterol level, blood pressure and body weight [7]. Several studies found that bus drivers are often exposed to cardiovascular disease [20].

Table 1. Comparison of previous researches

\begin{tabular}{|c|c|c|}
\hline Author & Methodology & Findings \\
\hline$[21]$ & $\begin{array}{l}\text { Survey } \\
\text { (128 intra-city bus } \\
\text { drivers) }\end{array}$ & $\begin{array}{l}\text { Activities such as usage of mobile phone can distract the intra- } \\
\text { city bus drivers and affect the safety of passengers. }\end{array}$ \\
\hline$[22]$ & $\begin{array}{l}\text { Unobtrusive video } \\
\text { ( } 70 \text { volunteer } \\
\text { drivers) }\end{array}$ & $\begin{array}{l}\text { The distraction of mobile phone on the performance of drivers } \\
\text { by measuring the levels of no hand on the steering wheel, eyes } \\
\text { directed inside rather than outside of the vehicle and lane } \\
\text { wandering or encroachments. }\end{array}$ \\
\hline$[16]$ & $\begin{array}{l}\text { Reviewing the } \\
\text { previous research }\end{array}$ & $\begin{array}{l}\text { The risk of having crash increase when there are activities } \\
\text { related with mobile phones such as dialling and texting while } \\
\text { driving. }\end{array}$ \\
\hline [23] & $\begin{array}{l}\text { Survey } \\
\text { (Transit bus driver) }\end{array}$ & $\begin{array}{l}\text { The rating of distraction for the driver via mobile phone is } \\
91 \% \text {. }\end{array}$ \\
\hline [24] & $\begin{array}{l}\text { Survey } \\
\text { (295 Drivers) }\end{array}$ & $\begin{array}{l}\text { Activities related with mobile phone which are dangerous and } \\
\text { could distract the driver. } \\
-73.9 \% \text { sending SMS text } \\
-61.3 \% \text { that dialling mobile phone. } \\
-46 \% \text { talking on hand-held mobile phone. }\end{array}$ \\
\hline [25] & $\begin{array}{l}\text { Simulator } \\
\text { (56 experienced } \\
\text { driver) }\end{array}$ & $\begin{array}{l}\text { Drivers glancing away from the roadway with less than } 2 \\
\text { seconds. } \\
\text { The distraction focused on In-Vehicle Information System } \\
\text { (IVIS) such as smart phone where long glances of the drivers } \\
\text { has become a major concern of the researcher. }\end{array}$ \\
\hline$[12]$ & Collective paper & $\begin{array}{l}\text { Based on the NHTSA crash data, the police report about } \\
\text { crashes which causes distraction are: - } \\
\text { - Tuning the radio. } \\
\text { - Speaking on the phone. } \\
\text { - Looking at billboard }\end{array}$ \\
\hline [19] & $\begin{array}{l}\text { Video } \\
\text { (28 Drivers) }\end{array}$ & $\begin{array}{l}\text { The longer the period of the driver's eye glancing off the road, } \\
\text { the higher the risk involved in a road crash. } \\
\text { The road condition has a significant impact on the driver's } \\
\text { distraction. }\end{array}$ \\
\hline [26] & $\begin{array}{l}\text { Simulator } \\
\text { (31 Drivers) }\end{array}$ & $\begin{array}{l}\text { Conducting an additional in-vehicle task will degrade the } \\
\text { driving performance. The activities include: - } \\
\text { - Tuning the radio. } \\
\text { - Conversation with passenger. } \\
\text { Driving performance is measured by: - } \\
\text { - Maintaining speed } \\
\text { - Reaction to hazardous situation } \\
\text { Drivers over } 60 \text { years old are proven to be more cautious while } \\
\text { driving as compared to the younger group of drivers. }\end{array}$ \\
\hline
\end{tabular}




\begin{tabular}{|c|c|c|}
\hline [27] & $\begin{array}{l}\text { Simulator } \\
\text { (36 Drivers) }\end{array}$ & $\begin{array}{l}\text { The findings of this research are: - } \\
\text { - Younger drivers are more exposed to distraction as they } \\
\text { tend to glance at IVIS more as compared to middle- } \\
\text { age drivers. } \\
\text { - Younger drivers tend to look off-road more than the } \\
\text { experienced drivers. }\end{array}$ \\
\hline [28] & $\begin{array}{l}\text { Simulator } \\
\text { (48 Drivers) }\end{array}$ & $\begin{array}{l}\text { When there is the presence of billboards, the effect to the driver } \\
\text { is: - } \\
\text { - Change of visual attention of the driver. } \\
\text { - Increase the time needed for the driver to respond to road } \\
\text { signs. } \\
\text { - Number of errors done have increased while driving. }\end{array}$ \\
\hline [29] & $\begin{array}{l}\text { Simulator } \\
\text { (12 Drivers) } \\
\text { Survey } \\
\text { (160 drivers) }\end{array}$ & $\begin{array}{l}\text { The findings of this research are: - } \\
-22 \% \text { of the drivers indicate that they are being distracted } \\
\text { and in a dangerous situation due to the presence of } \\
\text { advertising signs along the roadsides. } \\
-50 \% \text { of the respondents confirmed that they were } \\
\text { distracted by the roadside advertisement sign at least } \\
\text { once. }\end{array}$ \\
\hline [17] & $\begin{array}{l}\text { Reviewing previous } \\
\text { research }\end{array}$ & $\begin{array}{l}\text { The categories of distraction were identified in this research: - } \\
\text { - New technology information devices such as electronic } \\
\text { route guidance. } \\
\text { - Entertainment devices such as Radio. } \\
\text { - Mobile Phones. } \\
\text { - Interaction with passengers. } \\
\text { - Food consumption. } \\
\text { - Other distraction such as sneezing, smoking, operating } \\
\text { windows and reaching objects. }\end{array}$ \\
\hline [30] & $\begin{array}{l}\text { Survey } \\
\text { (6578 Drivers) }\end{array}$ & $\begin{array}{l}\text { The findings of this research are: - } \\
-20 \% \text { of drivers are engaged to secondary tasks while } \\
\text { driving. } \\
-11.3 \% \text { is conversing with passengers. } \\
-3.7 \% \text { is smoking. } \\
-1.3 \% \text { are talking in a handheld mobile phone. }\end{array}$ \\
\hline
\end{tabular}

Based on previous researches, the most commonly used method are survey and simulator study. With reference to the findings from the previous researches, there are generally a lot of factors of distraction among the drivers while driving. The most common distraction being found from the previous research arises from the usage of mobile phones. In addition, other researchers also found that glancing outside of the vehicle especially when looking at the billboard could distract the drivers from concentrating on driving safely.

\section{Conclusion}

In conclusion, this paper provides an overview regarding the factors of distraction among intrastate bus drivers as well as the methodology used by previous researchers. Those studies have little methodologies as researches related to ergonomics would not have any specific methodologies. Nevertheless, this research would help future researchers to have a better understanding on the factors of distraction among the intrastate bus drivers. 


\section{Acknowledgment}

The authors are supported by the Fundamental Research Grant Scheme (FRGS) Vot 1542, Office of Research, Innovation, Commercialization and Consultation (ORICC) Universiti Tun Hussein Onn Malaysia. The authors would also like to thank Rapid Bus Sdn Bhd and Prasarana Malaysia Berhad on the contribution and participation in this study.

\section{References}

[1] United Nations. (2014). World Urbanization Prospects: The 2014 Revision, Highlights(ST/ESA/SER.A/352). New York, United.

[2] Zhou, C., Dai, P., Wang, F., \& Zhang, Z. (2016). Predicting the passenger demand on bus services for mobile users. Pervasive and Mobile Computing, 25(2013), 48-66.

[3] Ponrahono, Z., Bachok, S., Ibrahim, M., \& Osman, M. M. (2016). Assessing Passengers' Satisfaction Level on Bus Services in Selected Urban and Rural Centres of Peninsular Malaysia. Procedia - Social and Behavioral Sciences, 222, 837-844.

[4] Le, T. P. L., \& Trinh, T. A. (2016). Encouraging public transport use to reduce traffic congestion and air pollutant: A case study of Ho Chi Minh City, Vietnam. Procedia Engineering, 142, 235-242.

[5] Bachok, S., Osman, M. M., \& Ponrahono, Z. (2014). Passenger's Aspiration Towards Sustainable Public Transportation System: Kerian District, Perak, Malaysia. Procedia - Social and Behavioral Sciences, 153, 553-565.

[6] Klein, M. C. A., van Lambalgen, R. M., \& Treur, J. (2010). An Agent Model for Analysis of Human Performance Quality. Web Intelligence and Intelligent Agent Technology (WI-IAT), 2010 IEEE/WIC/ACM International Conference on, 2, 181188.

[7] Tse, J. L. M., Flin, R., \& Mearns, K. (2006). Bus driver well-being review: 50 years of research. Transportation Research Part F: Traffic Psychology and Behaviour, 9(2), 89-114.

[8] La, Q. N., Duong, D. Van, Lee, A. H., \& Meuleners, L. B. (2015). Factors underlying bus-related crashes in Hanoi, Vietnam. Transportation Research Part F: Traffic Psychology and Behaviour.

[9] Ellison, A. B., Greaves, S. P., \& Bliemer, M. C. J. (2015). Driver behaviour profiles for road safety analysis. Accident Analysis and Prevention, 76, 118-132.

[11] Feng, S., Li, Z., Ci, Y., \& Zhang, G. (2016). Risk factors affecting fatal bus accident severity: Their impact on different types of bus drivers. Accident Analysis and Prevention, 86, 29-39.

[12] Ranney, T. a., Garrott, W. R., \& Goodman, M. J. (2000). NHTSA Driver Distraction Research: Past, Present, and Future. Driver Distraction Internet Forum, (233), 9.

[13] Regan, M. A., Lee, J. D., \& Young, K. L. (2009). Driver Distraction: Theory, Effects and Mitigation.

[14] Salmon, P. M., Young, K. L., \& Regan, M. A. (2011). Distraction “on the buses": A novel framework of ergonomics methods for identifying sources and effects of bus driver distraction. Applied Ergonomics, 42(4), 602-610.

[15] Törnros, J. E. B., \& Bolling, A. K. (2005). Mobile phone use - Effects of handheld and handsfree phones on driving performance. Accident Analysis and Prevention, 37(5), 902-909.

[16] Caird, J. K., Johnston, K. A., Willness, C. R., \& Asbridge, M. (2014). The use of meta-analysis or research synthesis to combine driving simulation or naturalistic 
study results on driver distraction. Journal of Safety Research, 49(February), 91-96.

[17] Stevens, A., \& Minton, R. (2001). In-vehicle distraction and fatal accidents in England and Wales. Accident Analysis and Prevention, 33(4), 539-545.

[18] Crundall, D., Van Loon, E., \& Underwood, G. (2006). Attraction and distraction of attention with roadside advertisements. Accident Analysis and Prevention, 38(4), 671-677.

[19] Peng, Y., \& Boyle, L. N. (2015). Driver's adaptive glance behavior to in-vehicle information systems. Accident Analysis and Prevention, 85, 93-101.

[20] Wood, D. (2001). Established and emerging cardiovascular risk factors. American Heart Journal, 141(2), S49-S57.

[21] Olapoju, O. M. (2016). Culture of distracted driving among intra-city commercial bus drivers in Ile-Ife, South-western Nigeria. Transportation Research Part F: Traffic Psychology and Behaviour, 42, 425-432.

[22] Stutts, J., Feaganes, J., Reinfurt, D., Rodgman, E., Hamlett, C., Gish, K., \& Staplin, L. (2005). Driver's exposure to distractions in their natural driving environment. Accident Analysis and Prevention, 37(6), 1093-1101.

[23] D 'souza, K. A., \& Maheshwari, S. K. (n.d.). Research framework for studying public transit bus driver distraction, 130, 137-148.

[24] Young, K. L., \& Lenné, M. G. (2010). Driver engagement in distracting activities and the strategies used to minimise risk. Safety Science, 48(3), 326-332.

[25] Borowsky, A., Horrey, W. J., Liang, Y., Garabet, A., Simmons, L., \& Fisher, D. L. (2016). The effects of brief visual interruption tasks on drivers' ability to resume their visual search for a pre-cued hazard. Accident Analysis and Prevention, 93, 207-216.

[26] Horberry, T., Anderson, J., Regan, M. A., Triggs, T. J., \& Brown, J. (2006). Driver distraction: The effects of concurrent in-vehicle tasks, road environment complexity and age on driving performance. Accident Analysis and Prevention, 38(1), 185-191.

[27] Donmez, B., Boyle, L. N., \& Lee, J. D. (2007). Safety implications of providing realtime feedback to distracted drivers. Accident Analysis and Prevention, 39(3), 581590.

[28] Edquist, J., Horberry, T., Hosking, S., \& Johnston, I. (2011). Effects of advertising billboards during simulated driving. Applied Ergonomics, 42(4), 619-626.

[29] Bendak, S., \& Al-Saleh, K. (2010). The role of roadside advertising signs in distracting drivers. International Journal of Industrial Ergonomics, 40(3), 233-236.

[30] Prat, F., Planes, M., Gras, M. E., \& Sullman, M. J. M. (2015). An observational study of driving distractions on urban roads in Spain. Accident Analysis and Prevention, $74,8-16$. 